\title{
Üniversite Öğrencilerinde Flört Şiddetinin Yaşam Kalitesi Üzerine Etkisi
}

\author{
The Effect of Dating Violence Among University Students on Quality of Life
}

\author{
Merve ISSIK ${ }^{1}$, Ümran DEMIRCAN² ${ }^{2}$ Nermin GÜRHAN ${ }^{3}$
}

\begin{abstract}
ÖZ
Ergenlik döneminde fark edilmeden maruz kalınabilen flört şiddeti yaşamı olumsuz etkilemektedir. Çalışmanın amacı üniversite öğrencilerinde flört şiddetinin yaşam kalitesi üzerine etkisini belirlemedir. Tanımlayıcı olan araştırmanın örneklemini 228 öğrenci oluşturdu. Veriler 'Kişisel Bilgi Formu', 'Flört Şiddetine Yönelik Tutum Ölçeği', 'Riskli Davranışlar Ölçeği Üniversite Formu' ve 'Whoqol-Bref' kullanılarak topland. Katılımcıların flört şiddetine yönelik puan ortalama dağılımları, Kadının Flörtte Uyguladığı Psikolojik Şiddete Yönelik Tutum $(1,77 \pm 0,61)$ ve Kadının Flörtte Uyguladığ Fiziksel Şiddete Yönelik Tutum $(1,76 \pm 0,69)$ puanlarıdır. Kadının Flörtte Uyguladığı Psikolojik Şiddete Yönelik Tutum Ölçeği, Genel Sağlık Durumunu negatif yönde etkilemektedir $(B=-, 131$ $\mathrm{p}<0,05)$. Genel sağlık durumu alanındaki değişimin \%2'si Kadının Flörtte Uyguladığı Psikolojik Şiddete Yönelik kabul düzeyini açıklamaktadır. Kadının Flörtte Uyguladığı Psikolojik Şiddet kabul düzeyi sosyal ilişkileri negatif yönde etkilemektedir $(\mathrm{B}=-, 156$ $\mathrm{p}<0,05)$. Bu alanındaki değişimin \%4'ü Kadının Flörtte Uyguladığı Psikolojik Şiddeti kabul düzeyini açıklamaktadır. Erkeğin Flörtte Uyguladığı Fiziksel Flört Şiddetine Yönelik Tutumlar Ölçeği, Çevreyi alanını negatif yönde etkilemektedir $(B=-, 122$ $\mathrm{p}<0,05)$. Çevre alanındaki değişimin \%2'si Erkeğin Flörtte Uyguladığı Fiziksel Flört Şiddet kabul düzeyini açıklamaktadır. Flört şiddet kabul düzeyi, bireyin sosyal ilişkilerini, çevresini ve sağlık durumunu etkilediğinden dolayı flört şiddetine yönelik farkındalık artırılmalıdır.
\end{abstract}

Anahtar Kelimeler: Flört şiddeti, Öğrenci, Yaşam kalitesi

\begin{abstract}
Dating violence, which can be exposed unnoticed during adolescence, negatively affects life. The aim of the study is to determine the effect of dating violence on the quality of life of university students. The sample of the descriptive study was 228 students. The data were collected by using "Personal Information Form", "Attitude Scale Towards Dating Violence", "Risky Behaviors Scale University Form" and "Whoqol-Bref". The mean score distribution of the participants for dating violence is the Attitude of Women towards Psychological Violence in Dating (1.77 \pm 0.61$)$ and the Attitude Towards Physical Violence by Women in Dating $(1.76 \pm 0.69)$. The Attitude Scale towards Psychological Violence Applied by Women in Dating negatively affects the General Health Status. 2\% of the change in the field of General Health Status explains the level of acceptance of the Psychological Violence Applied by Women in Dating. The level of acceptance of Psychological Violence Applied by Women in Dating Affects Social Relations negatively $(B=-, 156 \mathrm{p}<0,05) .4 \%$ of the change in this field explains the level of acceptance of Psychological Violence Applied by Women in Dating. The Attitudes Towards Physical Dating Violence Scale Applies by Man in Dating Affects Environment negatively $(B=-, 122 \mathrm{p}<0.05) .2 \%$ of the change in the field of environment explains Physical Dating Violence Acceptance Level Applied by Man in Dating. Since the level of acceptance of dating violence affects the social relations, environment and health of the individual, awareness of dating violence should be increased.
\end{abstract}

Keywords: Dating violence, Quality of life, Student

\footnotetext{
İlgili Üniversitenin Girişimsel Olmayan Klinik Araştırmalar Etik Kurulundan 91610558-604.01.02-sayısıyla etik izin ve kurum izni alınmıştır.

${ }^{1}$ Araştırma Görevlisi, Merve IŞIK, Gazi Üniversitesi Sağlık Bilimleri Fakültesi Hemșirelik Bölümü, Merve0606_90@hotmail.com, ORCID: 0000-0002-4857-2337

${ }^{2}$ Öğretim Görevlisi, Ümran DEMIRCAN, Sinop Üniversitesi Durağan Meslek Yüksekokulu İlk ve Acil Yardım Programı, umranaltinoz@hotmail.com, ORCID: 0000-0002-2975-4581

${ }^{3}$ Prof. Dr., Nermin GÜRHAN, Tokat Üniversitesi Sağlık Bilimleri Fakültesi Hemşirelik Bölümü, ngurhangurhan@ gmail.com , ORCID: 00000002-3472-7115 


\section{GíRIS}

Dünya Sağlık Örgütü şiddet kavramını; kişinin kendine, başka birine, gruba, topluma karşı güç kullanarak uyguladığı, yaralanma, ölüm, psikolojik zarar ile sonlanan uygulamalar olarak tanımlamıştır. ${ }^{1}$ Şiddet; gerginliğin artması, şiddet aşaması ve balayı aşaması olmak üzere döngüsel olarak üç aşamada gerçekleşir. Bu aşamaların süresi zaman geçtikçe azalmaktadır. ${ }^{2}$ Şiddet, üç grupta sinıflandırılmaktadır. Bunlardan ilki; öz kıyım girişimi, öz kıyım düşüncesi gibi bireyin kendisine yönelik uyguladığ 1 şiddet $^{3}$ ikincisi flört şiddeti, aile içi şiddet, akranlar arası şiddet gibi kişiler arası uygulanan şiddettir. Son olarak ise, terör saldırıları, savaşlar, etnik gruplar arasındaki çatışmaların yer aldığı kolaktif şiddettir. ${ }^{4}$

Kişilerarası uygulanan şiddet içinde yer alan flört şiddeti, partnerlerin birbirlerini cinsel, fiziksel, sözel ve duygusal açıdan istismara maruz birakması ve kisitlamalar getirmesidir. ${ }^{5}$ Bir başka tanıma göre, ilişkide karş1 tarafa baskılayıc1 tutumlar sergileyen, kontrol eden ve bireyin zarar görmesine sebep olan fiziksel, cinsel ve psikolojik girişimler bütünüdür. ${ }^{6}$ Flört şiddet türleri fiziksel flört şiddeti, psikolojik flört şiddeti, cinsel flört şiddeti ve siber flört istismarıdır. Fiziksel şiddet, DSM-5'te -eşin ya da birlikte olunan kişilerden birinin diğerine kaba güç kullanımı, bedensel başlığı altında- bir yılda partnerlerden birinin diğerine herhangi bir kötülügünün dokunulması veya dokunulabilecek olması sonucu bireyde korku uyandıran davranışlardır. Kaba güç kullanımı arasında, tokat atma, tekmeleme, vurma, itme, saç çekme, 1sırma, silah kullanma gibi eylemler yer alır. ${ }^{7}$

Flört şiddeti 17-29 yaş aralığında yaygın olarak görülmekte ve bu dönemde şiddet istismar davranış eğilimleri daha sık oranda ortaya çıkmaktadır. ${ }^{8}$ Adölesan ve genç erişkin dönemi, kişinin ergenliğe geçiş dönemi olup daha hassas, kırılgan ve deneyimsiz olduğu dönemdir. ${ }^{9}$

Flört ilişkisinde şiddet prevelansının araştırıldığı bir araştırmada, fiziksel şiddetin bireylerde yaşam boyu prevelansının \%13 ile
\%61 arasında olduğu saptanmıştır. ${ }^{10}$ Psikolojik flört şiddeti, partnere isim takma, alay etme, aile ve çevresiyle görüşmeyi kısıtlama şeklinde davranışlarla kişinin kendini değersiz hissetmesidir. Flörtte cinsel şiddet, DSM 5'de son bir yıl içinde partnere karş1, bireyin istememesine rağmen bask1 kurarak cinsel eylemde bulunmayı zorlaması ya da bulunmak zorunda birakması olarak belirtilmiştir. ${ }^{7}$ Flört tecavüzü, cinsel şiddet türlerinden biri olmakla birlikte lise ve üniversite yıllarında yaygın görülen bir sorundur. ${ }^{11,12}$ Flört şiddetinin bir başka türü olan siber flört istismarı, partnerlerden birinin diğerini telefon çağrıları, sms, e-mail gibi teknoloji ya da medya vasitasıyla takip veya rahatsız etmesidir. ${ }^{13}$ Farklı yönlerden birey üzerinde etkisi olan flört şiddetinin, toplumda görülme oranı yüksektir. Üniversite öğrencilerinde yapılan bir çalışmada, son bir yıl içinde kadınların \%31,6'sı, erkeklerin \%24,4'ü fiziki açıdan şiddet yaşamış olup, bir başka çalışmada ise, her $5 \mathrm{k}$ kz öğrenciden 1'i partneri tarafindan fiziksel ve/veya cinsel istismara uğramıştır. Ayrıca fiziksel ve cinsel flört şiddetine uğrama, madde kullanım riskini, sağlıksız kilo kontrolü davranışlarını, hamile kalma ve öz kıyım eğilimi ile ilişkili olduğu saptanmıştır. ${ }^{14,15}$

Flört şiddetinin ortaya çıkmasında birçok faktör etkili olabilmekte ve bu faktörler nedensel olabileceği gibi flört şiddetinin bir sonucu olarak da karşımıza çıkabilmektedir. Örneğin madde veya alkol kullanımı gibi riskli davranışlar sergilemek flört şiddeti davranışını artırdığı gibi, bu şiddetin bir sonucu olarak da riskli davranışlar sergilenebilmektedir. $\mathrm{Bu}$ kapsamda flört şiddetinin, diğer şiddetler gibi birey üzerinde olumsuz etkileri mevcuttur. Flört şiddetinin sağlıkla ilişkisini inceleyen birkaç araştırma fiziksel partner şiddetine maruz kalan genç yetişkinlerin sosyal destek kaynaklarının daha az olduğu, daha fazla alkol ve madde bağımlılığına yatkın oldukları, anksiyete, depresyon ve psikotik semptom belirtileri görülme oranının şiddet görmeyen akranlarına oranla daha fazla olduğu saptanmıştır. ${ }^{16} \mathrm{Bu}$ bağlamda flört şiddeti 
kişinin özgüveni üzerinde, benlik saygısında, yaşamının devamı sürecinde olumsuz etkilere sebep olabilir ve bireyin yaşam kalitesini olumsuz etkileyebilir. Öte yandan bireyde madde kullanımı, yeme bozuklukları, duygusal travma gibi psikiyatrik bozukluklar yanında, korku, anksiyete, çaresizlik, ümitsizlik, suçluluk, öfke gibi olumsuz duygular ortaya çıkabilir. ${ }^{2,17}$ Ayrıca anksiyete ve duygu durum bozuklukları belirtileriyle ortaya çıkan olumsuz duygulanımların kişi de birçok riskli davranışları tetiklediği belirtilmiştir. ${ }^{18} \mathrm{Bu}$ anlamda düşünüldüğünde flört şiddetinin adölesanlar da ve genç erişkinlerde yaşanıyor olması ve bu yaşlarda bireylerin deneyimsiz olmasından dolayı genellikle gizlenildiği belirtilmiştir. ${ }^{19}$ Genç erişkinlerde yaşam niteliği ve sağlığ geniş bir açıdan ele almak ve bu popülasyonla ilişkilerini belirlemek için ek araştırmalara ihtiyaç duyulur.

$\mathrm{Bu}$ doğrultuda, bu araştırmanın amacı üniversite öğrencilerinde flört şiddetinin yaşam kalitesi üzerine etkilerini araştırmaktır. Ayrıca üniversite öğrencileri arasında sağlıkla ilișkili yaşam niteliği ile flört şiddeti arasındaki ilişki nedir? sorusuna yanıt aranmıştır.

\section{MATERYAL VE METOT}

Tanımlayıcı tipte olan araştırma OcakSubat 2020 tarihleri arasinda Gazi Üniversitesi Hemşirelik Bölümünde yürütülmüştür. Araştırmanın evrenini, Gazi Üniversitesi Hemşirelik Bölümü öğrencilerinde öğrenim gören hemşirelik 1. ve 2. sınıf öğrencileri oluşturmuştur. Araştırmada örneklem büyüklüğü oluşturulmamış, evrenin tamamına ulaşılmaya çalışılmıştır. Araştırmayı kabul eden 228 öğrenci araştırmaya dahil edilmiştir. Veriler araştırmacılar tarafından toplanmış olup veri toplama araçlarının uygulanması yaklaşık 25 dakika sürmüştür. Araştırmanın bağımlı değişkenleri flört ilişkisinde yaşam kalitesi ve riskli davranışlardır. Yaş, cinsiyet, annenin eğitim durumu, babanın eğitim durumu, mevcut ilişki durumu bağımsız değişkenlerdir. Verilerde Kişisel Bilgi Formu, Flört Şiddetine Yönelik Tutum Ölçeği, Riskli Davranışlar Ölçeği Üniversite Formu, Dünya Sağlık Örgütü Yaşam Kalitesi Ölçeği Kısa Formu Türkçe Versiyonu kullanılmıştır.

\section{Kişisel Bilgi Formu}

Kat1lımc1ların sosyo-demografik bilgileri ve flört şiddeti nitelikleri ile ilgili sorular yer alır.

\section{Flört Şiddetine Yönelik Tutum Ölçekleri (FŞYTÖ)}

Flört şiddetine yönelik tutum ölçekleri Price, Byers ve Flört Şiddeti Araştırma Ekibi
(1999) aracılığı ile gerçekleştirilmiştir. Erkeğin Flörtte Uyguladığı Psikolojik Şiddete Yönelik Tutum Ölçeği, Erkeğin Flörtte Uyguladığı Fiziksel Şiddete Yönelik Tutum Ölçeği, Kadının Flörtte Uyguladığı Psikolojik Şiddete Yönelik Tutum Ölçeği, Kadının Flörtte Uyguladığı Fiziksel Şiddete Yönelik Tutum Ölçeği boyutlarından oluşan Flört Şiddetine Yönelik Tutum Ölçeği kız ve erkeklerin flörtte psikolojik, fiziksel ve cinsel şiddete yönelik tutumlarını belirlemeye yöneliktir. ${ }^{20}$ Ölçeğin Türkçe geçerlilik ve güvenirlilik çalışması 2013 yılında Yumuşak tarafından yapılmıştır. ${ }^{21}$ Ölçekten alınan puan düzeyi arttıkça bireyin flört şiddetine yönelik düzeyinin yüksek olduğu gösterilmektedir. Ölçek 'kesinlikle katılıyorum', 'katılıyorum', 'kararsızım', 'katılmıyorum', 'kesinlikle katılmıyorum' olmak üzere beşli likert tipidir.

\section{Riskli Davranışlar Ölçeği Üniversite Formu (RDÖÜF)}

Riskli Davranışlar Ölçeği Üniversite Formu, Gençtanırım tarafından hazırlanan Riskli Davranışlar Ölçeğinden yararlanılmış olup, üniversite öğrencilerinin gelişim düzeyleri göz önüne alınarak geliştirilmiştir. $^{22}$ Ölçek antisosyal davranışlar, alkol kullanımı, sigara kullanımı, özkıyım düşüncesi, beslenme alışkanlıkları, okul terki ve madde kullanımı boyutları olup 60 maddeden oluşmaktadır. Ölçek 'her zaman', 'genellikle', 'bazen', 'nadiren' ve 
'hiçbir zaman' şeklinde beşli likert tipidir. Toplam ölçek puanı bulunmamaktadır. Alt ölçeklerin her biri ayrı ayrı değerlendirilmektedir. Alt ölçeklerden alınan puan düzeyi yükseldikçe o alt ölçekteki risk düzeyi daha yüksektir.

\section{Dünya Sağlık Örgütü Yaşam Kalitesi Ölçeği- Kısa Form (WHOQOL-BREF)}

Dünya Sağlik Örgütü Yaşam Kalitesi Ölçeği- Kısa Form (WHOQOL-BREF) ölçeği, 27 sorudan oluşmaktadır. Ölçeği iki soru genel olup dört alan (26 soru) ve bir ulusal alan (1 soru) oluşturmaktadır. ${ }^{23}$ Ölçekte yer alan 26 soru içinden iki soru bireyin yaşam kalitesini değerlendirmektedir. $\mathrm{Bu}$ sorular içinden biri tamamen sağlik, diğeri yaşam kalitesi puanlarını hesaplamaktadır. Sorular son 15 gün göz önünde bulundurularak cevaplanacaktır. Ölçek likert tipinden oluşmakta ve sorular kapalı uçludur. WHOQOL-BREF ölçeğindeki sorular, 'şiddet yanıt göstergesi', 'kapasite yanıt ölçeği', 'sıklık yanıt ölçeği' ve 'değerlendirme' olmak üzere dört yanıt skalasından oluşmuştur. $\mathrm{Bu}$ skalalardan şiddet yanıt göstergesi, bireyin ağrı belirtisi gibi belli bir durumunu ne ölçüde yaşadığı ve şiddetli biçimde yaşanan tecrübelerin bireyin yaşam tarzını nasıl etkileyeceği yönünde düşünülmüştür. Kapasite yanıt ölçeği, kişinin olay, duygu ve davranışı gösterebilme becerisini belirler. Kapasitenin mevcut durumlar üzerinde bulunduğu koşullarda yaşam kalitesini etkileyebileceği varsayılmıştır. Sıklık yanıt ölçeği, bireyin herhangi bir durum ya da davranış sıklığının yaşam kalitesini etkileyebileceği düşünülmüştür. Değerlendirme ise, olaylar karşısında verilen yanıtların pozitif yönde olması, bireyin yaşam tarzının daha yüksek olduğu anlamına gelebileceği yönündedir. ${ }^{23}$ WHOQOL-BREF ölçeği, bedensel alan, psikoloji alanı, sosyal ilişkiler alanı ve çevre alanından oluşmaktadır. Bedensel alan bireyin, çalışabilme, bedensel hareketlilik gibi günlük ihtiyaçlarını yürütebilmesi, uyku, dinlenme gibi fizyolojik ihtiyaçlarını karşılayabilmesi bölümlerini içerir. Bireyin bilişsel değerlendirmeleri, beden algısı, benlik saygısı, bireysel inançları gibi bölümler psikolojik alanı oluşturur. Bireyin çevresindeki kişilerle ilişkileri, sosyal destek varlığ 1 ve cinsel yaşam bölümleri ise sosyal ilişkiler alanı içine girmektedir. Çevre alanı, kişinin fiziki çevresi, ev ortamı, maddi kaynakları beraberinde boş zamanları etkin değerlendirme, bilgi ve beceri edinme bölümlerini oluşturur. ${ }^{23}$

\section{Verilerin Analizi}

Araştırmanın verileri SPSS.20 paket programı ile belirlenmiştir. Normallikte Shapiro-Wilk testi kullanılmıştır. Araştırma bulguları normal dağılıma uygun olmadığından non parametrik testler uygulanmıştır. Sonuçlar, $p<0,05$ ise anlamlı olarak değerlendirilmiştir. Flört Şiddeti ve Yaşam Kalitesi arasındaki ilişki Pearson korelasyon, etkisi regresyon testiyle değerlendirilmiştir. Flört Şiddeti, Riskli Davranışlar Ölçeği ve Antisosyal Davranışlar, İntihar Eğilimi, Beslenme Alışkanlıkları ile Okul Terki boyutlarının 2 kategorili değişkenlere göre farklılık göstermesi t testi ile, 3 ve daha fazla kategorili değişkenlere göre farklılık göstermesi ANOVA testi ile hesaplanmıştır. Alkol Kullanımı, Sigara Kullanımı ve Madde Kullanımının 2 kategorili değişkenlere göre farkl1l1k göstermesi Mann Whitney testi ile, 3 ve daha fazla kategorili değişkenlere göre farklıl1k göstermesi Kruskal Wallis testi ile incelenmiştir.

\section{Araştırmanın Etik Yönü}

Gazi Üniversitesi Girişimsel Olmayan Klinik Araştırmalar Etik Kurulundan 7 Ocak 2020 tarihinde 91610558-604.01.02-sayısiyla etik izin alınmıştır. Ayrıca Gazi Üniversitesi Sağlık Bilimleri Fakültesi Hemşirelik Bölümünden uygulama için yazılı izin alınmıştır.

\section{Araştırmanın Sınırlılıkları}

$\mathrm{Bu}$ araştırmanın üniversite öğrencileri 1 . ve 2. sınıflar ile yapılmış olması bulguların genellenebilir olmasını kısıtlamaktadır. 


\section{BULGULAR VE TARTIŞMA}

Çalışmaya katılan toplam 228 bireyin \%86,4'ü kadın, \%13,6's1 erkektir. Katılımcıların \%37,3'ü 19 yaşında, $\% 59,5$ 'inin annesi ilköğretim düzeyinde ve $\% 40,8$ 'inin babası ilköğretim düzeyinde eğitime sahiptir. Katılımcıların \%30,8'inin mevcut bir ilişki durumunun olduğu, mevcut ilişki durumu olanlarında yarısından fazlasının $(\% 58,9)$ bir yıl veya daha az bir birliktelikleri olduğu belirlenmiştir. Herhangi bir psikiyatrik rahatsılık oranı \%3,5 iken psikiyatrik ilaç kullanma oranı \%1,8'dir.

Üniversite öğrencilerinde Erkeğin Flörtte Uyguladığı Psikolojik Şiddete Yönelik Tutumları $\quad(p=, 000), \quad$ Erkeğin $\quad$ Flörtte Uyguladığ1 Fiziksel Şiddete Yönelik Tutumları $\quad(p=, 002), \quad$ Kadının Flörtte Uyguladığı Fiziksel Şiddete Yönelik Tutumları cinsiyete göre anlamlı farklılık göstermektedir $(\mathrm{p}=, 009)$. Erkek ile kadınlar arasında Erkeğin Flörtte Uyguladığ Psikolojik Şiddete Yönelik Tutum Ölçeği, Erkeğin Flörtte Uyguladığ 1 Fiziksel Flört Şiddetine Yönelik Tutumlar Ölçeği ve Kadının Flörtte Uyguladığı Fiziksel Şiddete Yönelik Tutum Ölçeği açısından anlamlı farklılık bulunmaktadır $(\mathrm{p}<0,05)$. Erkek öğrencilerin Erkeğin Flörtte Uyguladığı Psikolojik Şiddete Yönelik Tutum puan ortalamaları k1z öğrencilerin Erkeğin Flörtte Uyguladığı Psikolojik Şiddete Yönelik Tutum puan ortalamalarından daha yüksektir. Erkek öğrenciler erkeklerin gösterdiği hem psikolojik şiddeti hem de fiziksel şiddeti daha yüksek düzeyde kabul etmişlerdir. Erkeklerin flört şiddetini genel olarak kabul düzeylerinin kadınlarınkinden yüksek olması sonucu, diğer araștırmaların sonuçları ile benzerlik göstermektedir. ${ }^{24,25}$

Erkek öğrencilerin Erkeğin Flörtte Uyguladığ1 Fiziksel Şiddete Yönelik Tutum puan ortalamaları kız öğrencilerin Erkeğin Flörtte Uyguladığı Fiziksel Şiddete Yönelik Tutum puan ortalamalarından daha yüksektir. Kadının Flörtte Uyguladığı Fiziksel Şiddete Yönelik Tutum puan ortalamaları erkek öğrencilerde kız öğrencilerin Kadının Flörtte Uyguladığı Fiziksel Şiddete Yönelik Tutum puan ortalamalarından daha yüksektir. K1z öğrencilerde erkeğin flörtte uyguladığ1 psikolojik ve fiziksel flört şiddetini kabul seviyeleri erkek öğrencilere göre daha düşüktür. Yumuşak (2013) tarafından yapılan bir çalışmada mevcut araştırmayı destekleyen bulgulara yer vermiştir. ${ }^{21}$ Yapılan bir başka çalışmada yine benzer bulgular yer almaktadır. Çalışmaya göre, erkeklerin kadınlara göre erkeklerin uyguladığ fiziksel ve psikolojik şiddeti daha fazla kabul ettikleri belirlenmiştir. Yine aynı çalışmada erkeklerin kadınlara oranla kadınların gösterdiği psikolojik ve fiziksel şiddeti kabul düzeyi daha fazladır. Erkeğin ve kadının flörtte uyguladığı psikolojik ve fiziksel şiddete yönelik kabul düzeyinin yüksek olması, kişilerin yetiştirilme tarzlarının, toplumsal cinsiyet rollerin, ataerkil toplum yapısının etkili olabileceği düşünülebilir.

Ayrıca kız öğrencilerin, kadının flörtte gösterdiği fiziksel flört şiddetini kabul seviyeleri erkeklerden daha düşüktür. Üniversite öğrencilerinin Erkeğin Flörtte Uyguladığı Psikolojik Şiddete Yönelik Tutumları yaşa göre anlamlı farklılık göstermektedir $(p=, 008) .21$ yaşında olan öğrencilerin Erkeğin Flörtte Uyguladığı Psikolojik Şiddete Yönelik Tutum puan ortalaması diğer yaş gruplarına oranla yüksek bulunmuştur ve bu yaş grubunda erkeğin flörtte uyguladığ1 psikolojik şiddet kabul düzeyi daha fazladır. Y1ldırım (2016)'ın yapmış olduğu bir çalışmada 23 yaş ve üzeri olan öğrencilerin diğer yaş gruplarına göre flört şiddetine karşı genel tutumları olumsuz yöndedir. ${ }^{26}$ Ayrıca yaşın artmasıyla birlikte kadının flörtte uyguladığı psikolojik şiddeti kabul düzeyi azalmaktadır. ${ }^{26}$ İftar (2016) çalışmasında ise, 17-19 yaş grubunda olan bireylerde şiddete yönelik tutum puanlarının diğer yaş gruplarına göre yüksek olduğunu saptamıştır. $^{3}$ Çalışmamızda en fazla 21 yaşında olan bireylerin erkeğin flörtte uyguladığı psikolojik şiddeti kabul düzeyinin 22 yaş ve üzeri olan ve ayrıca diğer yaş gruplarına göre daha yüksek olması, toplumun kültürel yapisinın geleneksel olması düşünülebilir. Ayrıca daha genç 
gruplarda puan ortalamasının düşük olması, kişilerin yaşamlarında flört ilişkisini daha az deneyimlemesi bunun haricinde üniversiteye daha yeni uyum sağlayabilmesi gibi farklı yaşamsal olayların olması kişilerin şiddete yönelik tutumlarının daha olumlu düzeyde olmasına neden olabilir.

Üniversite öğrencilerinin anne ve baba eğitim durumu ile Kadının Flörtte Uyguladığ Fiziksel Şiddete Yönelik Tutum Ölçeği açısından anlamlı farklılık bulunmaktadır $(\mathrm{p}<0,05)$. Annesi okuma yazma bilmeyen öğrencilerin Kadının Flörtte Uyguladığı Fiziksel Şiddete Yönelik Tutum puan ortalaması diğer anne eğitim düzeylerine göre yüksek bulunmuştur. Üniversite öğrencilerinin Kadının Flörtte Uyguladığı Fiziksel Şiddete Yönelik Tutumları baba eğitim düzeyine göre de anlamlı farklılık göstermektedir $(\mathrm{p}<0,05)$. Babası okuma yazma bilmeyen öğrencilerin kadının flörtte uyguladığı fiziksel flört şiddetini kabul düzeyleri diğer eğitim düzeylerine sahip olan öğrencilere göre daha yüksek olduğu belirlenmiştir (Tablo 1). Okuma- yazması olmayan bireylerde kadının flörtte uyguladığı fiziksel şiddeti kabul düzeyi daha fazladır. Bir diğer çarpıcı sonuçta kadının flörtte uyguladığı fiziksel şiddeti kabul düzeyi ikinci sırada en yüksek olan anne ve babasının eğitim düzeyi üniversite ve üstü olan bireylerde olduğu saptanmıştır. Anne eğitim düzeyi düşük olan öğrencilerde flört şiddetini kabul düzeyinin yüksek olması yapılan diğer bazı çalıșmaların sonuçlarıyla benzerlik göstermektedir. ${ }^{27,28}$ Anne eğitim düzeyi düşük olan öğrencilerde flört şiddetinin kabul düzeyinin daha yüksek oranda olmas1, annenin geleneksel tutum sergilemesi ve çocukların rol model olmasına bağlanabilir. İkinci sırada yer alan anne eğitim düzeyi yüksek olan öğrencilerde flört şiddetine yönelik tutumun daha olumlu düzeyde olması ise, ebeveynlerin yeteri kadar çocuklarına vakit ayıramıyor oluşu olabilir. Bu durumun daha niteliksel çalışmalarla desteklenmesi önerilir. Baba eğitim düzeyi ile kadının fiziksel flört şiddetine yönelik kabul düzeyi arasında istatistiksel olarak anlamlı düzeyde ilişki vardır. Ancak diğer flört şiddetine yönelik tutum ölçekleri ile baba eğitim düzeyi arasında anlamlı ilişki saptanmamıştır. Çalışmamızın bulguları baba eğitim düzeyinin kadının flörtte uyguladığı fiziksel şiddeti kabul düzeyinin yüksek olduğunu göstermiştir.

Çalışmamızda üniversite öğrencilerinin mevcut ilişki durumu flört şiddetine yönelik tutum ölçeği puanını etkilememiştir $(p>0,05)$. (Tablo 1).

Tablo 1. FŞYTÖ Demografik ve Flört Şiddetine İlişkin Özellikler Açısından İncelenmesi

\begin{tabular}{|c|c|c|c|c|}
\hline $\begin{array}{l}\text { Demografik ve flört } \\
\text { şiddetine ilişkin } \\
\text { özellikler }\end{array}$ & $\begin{array}{l}\text { Erkeğin Flörtte } \\
\text { Uyguladığı } \\
\text { Psikolojik } \\
\text { Şiddete } \\
\text { Yönelik Tutum } \\
\text { Ölçeği }\end{array}$ & $\begin{array}{l}\text { Erkeğin Flörtte } \\
\text { Uyguladığı } \\
\text { Fiziksel Flört } \\
\text { Şiddetine } \\
\text { Yönelik } \\
\text { Tutumlar Ölçeği }\end{array}$ & $\begin{array}{l}\text { Kadının Flörtte } \\
\text { Uyguladığı } \\
\text { Psikolojik } \\
\text { Şiddete Yönelik } \\
\text { Tutum Ölçeği }\end{array}$ & $\begin{array}{l}\text { Kadının Flörtte } \\
\text { Uyguladığı } \\
\text { Fiziksel Şiddete } \\
\text { Yönelik Tutum } \\
\text { Ölçeği }\end{array}$ \\
\hline & Ort \pm Ss & Ort \pm Ss & Ort \pm Ss & Ort \pm Ss \\
\hline $\begin{array}{l}\text { Cinsiyet } \\
\text { Erkek } \\
\text { Kadın } \\
\text { test değeri }\end{array}$ & $\begin{array}{l}2,21 \pm 0,69 \\
1,55 \pm 0,43 \\
\mathbf{t}=\mathbf{7 , 2 4 3} \\
\mathbf{p}=, \mathbf{0 0 0} *\end{array}$ & $\begin{array}{l}1,77 \pm 0,64 \\
1,37 \pm 0,48 \\
\mathbf{t}=\mathbf{3 , 3 4 3} \\
\mathbf{p}=, \mathbf{0 0 2} *\end{array}$ & $\begin{array}{l}1,95 \pm 0,66 \\
1,74 \pm 0,60 \\
t=1,738 \\
p=, 084\end{array}$ & $\begin{array}{l}2,06 \pm 0,70 \\
1,71 \pm 0,67 \\
\mathbf{t = 2 , 6 5 4} \\
\mathbf{p}=, \mathbf{0 0 9} *\end{array}$ \\
\hline
\end{tabular}


Tablo 1 (Devamı). FŞYTÖ Demografik ve Flört Şiddetine İlişkin Özellikler Açısından İncelenmesi

\begin{tabular}{lllll}
\hline Yaş & & & & \\
17 ve 18 & $1,49 \pm 0,44$ & $1,26 \pm 0,36$ & $1,72 \pm 0,60$ & $1,67 \pm 0,72$ \\
19 & $1,58 \pm 0,44$ & $1,41 \pm 0,53$ & $1,72 \pm 0,52$ & $1,74 \pm 0,62$ \\
20 & $1,71 \pm 0,56$ & $1,55 \pm 0,58$ & $1,80 \pm 0,69$ & $1,82 \pm 0,71$ \\
21 & $1,91 \pm 0,69$ & $1,45 \pm 0,53$ & $1,87 \pm 0,66$ & $1,76 \pm 0,76$ \\
22 ve üzeri & $1,63 \pm 0,54$ & $1,52 \pm 0,56$ & $1,93 \pm 0,82$ & $1,99 \pm 0,76$ \\
test değeri & $\mathbf{F}=\mathbf{3 , 5 1 8}$ & $\mathrm{F}=2,128$ & $\mathrm{~F}=, 631$ & $\mathrm{~F}=, 649$ \\
& $\mathbf{p}=, \mathbf{0 0 8}$ & $\mathrm{p}=, 078$ & $\mathrm{p}=, 041$ & $\mathrm{p}=, 628$ \\
\hline Anne eğitim durumu & & & & \\
okuryazar değil & $1,73 \pm 0,49$ & $1,57 \pm 0,62$ & $1,88 \pm 0,53$ & $2,09 \pm 0,74$ \\
İlköğretim & $1,65 \pm 0,55$ & $1,40 \pm 0,52$ & $1,75 \pm 0,61$ & $1,70 \pm 0,67$ \\
lise & $1,55 \pm 0,44$ & $1,39 \pm 0,47$ & $1,71 \pm 0,64$ & $1,66 \pm 0,59$ \\
üniversite ve üstü & $1,74 \pm 0,77$ & $1,43 \pm 0,28$ & $1,97 \pm 0,96$ & $2,00 \pm 0,96$ \\
test değeri & $\mathrm{F}=, 942$ & $\mathrm{~F}=, 993$ & $\mathrm{~F}=, 814$ & $\mathbf{F}=\mathbf{3 , 7 6 6}$ \\
& $\mathrm{p}=, 421$ & $\mathrm{p}=, 397$ & $\mathrm{p}=, 487$ & $\mathbf{p}=\mathbf{, 0 1 1}$ \\
\hline Baba eğitim durumu & & & & \\
okuryazar değil & $1,75 \pm 0,52$ & $1,54 \pm 0,66$ & $1,90 \pm 0,62$ & $2,18 \pm 0,84$ \\
İlköğretim & $1,65 \pm 0,53$ & $1,47 \pm 0,57$ & $1,82 \pm 0,64$ & $1,77 \pm 0,64$ \\
lise & $1,64 \pm 0,53$ & $1,37 \pm 0,46$ & $1,69 \pm 0,56$ & $1,70 \pm 0,68$ \\
üniversite ve üstü & $1,52 \pm 0,49$ & $1,33 \pm 0,36$ & $1,74 \pm 0,65$ & $1,56 \pm 0,61$ \\
test değeri & $\mathrm{F}=, 786$ & $\mathrm{~F}=1,281$ & $\mathrm{~F}=1,050$ & $\mathbf{F}=\mathbf{3 , 9 0 1}$ \\
& $\mathrm{p}=, 503$ & $\mathrm{p}=, 282$ & $\mathrm{p}=, 371$ & $\mathbf{p}=\mathbf{, 0 1 0}$ \\
\hline Mevcut ilişki durum & & & & \\
evet & $1,70 \pm 0,52$ & $1,49 \pm 0,60$ & $1,81 \pm 0,64$ & $1,70 \pm 0,67$ \\
hayir & $1,61 \pm 0,52$ & $1,39 \pm 0,46$ & $1,75 \pm 0,60$ & $1,79 \pm 0,70$ \\
test değeri & $\mathrm{t}=1,168$ & $\mathrm{t}=1,223$ & $\mathrm{t}=, 707$ & $\mathrm{t}=, 948$ \\
& $\mathrm{p}=, 244$ & $\mathrm{p}=, 224$ & $\mathrm{p}=, 480$ & $\mathrm{p}=, 344$ \\
\hline
\end{tabular}

$* \mathrm{p}<0,05$

Katılımcıların Erkeğin Flörtte Uyguladığı Psikolojik Şiddete Yönelik Tutum, Erkeğin Flörtte Uyguladığı Fiziksel Şiddete Yönelik Tutum, Kadının Flörtte Uyguladığ 1 Psikolojik Şiddete Yönelik Tutum ve
Kadının Flörtte Uyguladığı Fiziksel Şiddete Yönelik Tutum Ölçeklerinden aldıkları puan ortalamalar1 sirasi ile $1,64 \pm 0,52,1,42 \pm 0,52$, $1,77 \pm 0,61$ ve $1,76 \pm 0,69$ 'dur (Tablo2).

Tablo 2. FŞYTÖ Puan Ortalamalarının Dağılımı

\begin{tabular}{llc}
\hline FŞYTÖ Alt boyutları & Ort \pm Ss & Min-Max \\
\hline $\begin{array}{l}\text { Erkeğin Flörtte Uyguladığı Psikolojik Şiddete Yönelik } \\
\text { Tutum Ölçeği }\end{array}$ & $1,64 \pm 0,52$ & $1,00-4,07$ \\
\hline $\begin{array}{l}\text { Kadının Flörtte Uyguladığı Fiziksel Şiddete Yönelik Tutum } \\
\text { Ölçeği }\end{array}$ & $1,42 \pm 0,52$ & $1,00-3,33$ \\
\hline $\begin{array}{l}\text { Erkeğin Flörtte Uyguladığı Psikolojik Şiddete Yönelik } \\
\text { Tutum Ölçeği }\end{array}$ & $1,77 \pm 0,6$ & $1,00-3,36$ \\
\hline $\begin{array}{l}\text { Kadının Flörtte Uyguladığı Fiziksel Şiddete Yönelik Tutum } \\
\text { Ölçeği }\end{array}$ & $1,76 \pm 0,69$ & $1,00-4,08$ \\
\hline
\end{tabular}

Üniversite öğrencilerinin anti sosyal davranışlar, sigara kullanımı, okul terki ve madde kullanımı riskli davranışlar boyutları cinsiyet değişkenine göre anlamlı farklılık göstermektedir $(p<0,05)$. Erkek öğrencilerin anti sosyal davranışlar boyutu puan ortalamas1, sigara kullanımı boyutu ortalamas1, okul terki boyut ortalaması ve madde kullanımı boyutu ortalaması k1z öğrencilere göre daha yüksek olduğu saptanmıştır. Erkek öğrencilerin anti sosyal davranış gösterme eğilimleri, sigara ve madde kullanım davranışları ve okulu bırakma durumu k1z öğrencilere oranla yüksek düzeydedir (Tablo 3). Yapılan çalışmalar bu durumu desteklemektedir ve sigara kullanımı, okul terki gibi olumsuz davranışların erkek öğrencilerde daha fazla 
görülmesinde, davranışların akran grupları tarafindan desteklenmesi ve kullanımın yaygın olması veya akran gruplarına dahil olabilme gibi etkenler olabilir. ${ }^{29,30,31}$ Araştırmada, erkek öğrencilerde anti sosyal davranış gösterme oranı kız öğrencilere göre daha yüksektir. Anti sosyal davranışlar, kasıtlı olarak diğer bireylerin eşyalarına hasar verme, okuldan ya da evden ayrilma davranış1 gösterme ve fiziksel şiddetin de yer aldığı davranışlardır. Anti sosyal davranışın bir parçası olan şiddet olaylarında okullarda önemli artışlar olmaktadır. ${ }^{32}$ Yapılan çalışmalar, 10 gençten yaklaşık 1'inin geçen yıl şiddet mağduriyetiyle (kasitlı olarak vurulduğu, tokatlandığ 1 veya fiziksel olarak bir erkek arkadaşın veya kız arkadaşının yaraladığı) bildirildiğini bulmuştur. Her 10 kızdan 1'i yaşamı boyu cinsel saldırı öyküsü bildirmiştir. Şiddet mağduriyeti, depresif belirtiler, cinsel yönelim ve diğer riskli davranışlar intihar girişimleriyle güçlü bir şekilde ilişkilidir. ${ }^{33}$ Öğrencilerin gösterdiği bu davranışlar hem kişilerin gelişimlerini hem de diğer akran gruplarını olumsuz yönde etkilemektedir. Aynı zamanda kişilerin fiziksel sağlığının yanında ruh sağlığını da olumsuz yönde etkileyebilmektedir. Flört şiddetinin sağlıkla ilişkisini araştıran birkaç araştırma, fiziksel partner şiddeti uygulayan adölesanlarda daha az sosyal destek kaynaklarına sahip oldukları, daha fazla alkol ve madde bağımlılığ anksiyete, depresyon gibi psikotik semptomların arttığ belirtilmiştir. $^{16}$

Üniversite öğrencilerinin RDÖÜF alt boyutlarından madde kullanımı yaşa göre anlamlıdır $(p<0,05) .22$ yaş ve üstü olan öğrencilerin puan ortalaması diğer yaş gruplarına göre daha yüksek düzeydedir. Ergenlerde sigara, alkol ve madde kullanımı üzerinde sosyo demografik değişkenlerin, psikolojik sağlığın, ebeveynlerden ve arkadaş çevresinden algılanan desteğin tahmin edilebilirliğine bakılmıştır. Çalışma bulgularında yaş ilerledikçe madde kullanımına yönelik riskli davranışlarda artış olduğunu saptamıştır. ${ }^{34}$ Akran gruplarında yer alma ve maddeye ulaşma kolaylığı yaş ilerledikçe daha kolay olabileceğinden riskli davranış olasılığının arttığı düşünülmektedir. Ailenin eğitim düzeyi düştükçe yeteri kadar sosyal destek gösteremeyebilir. Ayrıca anti sosyal davranışın önemli göstergelerinden biri de saldırganlık boyutudur. Yapılan bir çalışmada ailelerinden algıladıkları sosyal destek düzeyi ile öğrencilerin saldırganlık düzeyi incelenmiştir. Sonuçta algılanan sosyal destek düzeyi artıkça saldırganlık davranışlarının azaldığı, anne ve baba eğitim düzeyi yüksek olanların daha yüksek düzeyde çevrelerinden sosyal destek algıladıkları belirlenmiştir. ${ }^{35}$ Sonuç olarak sosyal ilişkileri destekleme riskli davranışları azaltmakta önemli olabilir.

Üniversite öğrencilerinin anti sosyal davranışlar alanı anne eğitim durumu ve baba eğitim durumuna göre farklılık göstermektedir $(\mathrm{p}<0,05)$. Annesi okuma yazma bilmeyen öğrencilerin anti sosyal davranış boyutu puan ortalaması ve babası okuma yazma bilmeyen öğrencilerin anti sosyal davranış boyutu puan ortalaması anne ve baba eğitim düzeylerine göre daha yüksektir. Anne ve babası okuma yazma bilmeyen üniversite öğrencilerinin anti sosyal davranış gösterme boyutu daha yüksek olduğu saptanmıştır.

Çalışmamızda üniversite öğrencilerinin alkol kullanımı ve sigara kullanımı daha önce var olan bir romantik ilişki varlığ bakımından anlamlı farklılık göstermektedir $(p<0,05)$. Öğrencilerden daha önce bir ilişki yaşamış olanların alkol kullanımı boyutu puan ortalaması ve sigara kullanımı boyutu puan ortalaması daha önce hiçbir ilişkisi olmayanlara göre yüksek düzeydedir.

Ayrıca üniversite öğrencilerinin sigara kullanımı ve madde kullanımı ile mevcut bir romantik ilişki varlığı arasında anlamlı farklılık belirlenmiştir $\quad(p<0,05)$. Öğrencilerden mevcut ilişkisi bulunanların sigara kullanım boyutu puan ortalaması ve madde kullanım boyutu puan ortalamas1 mevcut ilişkisi olmayanlara göre daha yüksek düzeydedir. Mevcut ilişkisi olan öğrencilerin sigara kullanımı ve madde kullanımı davranış durumu, ilişkisi olmayanlara göre daha yüksek düzeydedir (Tablo 3). Geçmişte ilişkisi olan kişilerde alkol ve sigara 
kullanımına yönelik riskli davranış oranı flört ilişkisi olmayan kişilere göre daha yüksektir. Olumsuz riskli davranışların, ergenler arasında bir güç göstergesi olabileceği ya da uygun olmayan etkisiz baş etme yöntemlerine yönelebildiklerinden kaynaklı olduğu düşünülebilir.

Tablo 3. RDÖÜF Boyutlarının Demografik ve Flört Şiddetine İlişkin Özellikler Açısından İncelenmesi

\begin{tabular}{|c|c|c|c|c|c|c|c|}
\hline $\begin{array}{l}\text { Demografik ve } \\
\text { flört şiddeti } \\
\text { özellikleri }\end{array}$ & $\begin{array}{l}\text { Antisosyal } \\
\text { Davranışlar }\end{array}$ & $\begin{array}{l}\text { Alkol } \\
\text { Kullanımı }\end{array}$ & $\begin{array}{l}\text { Sigara } \\
\text { Kullanımı }\end{array}$ & $\begin{array}{l}\text { İntihar } \\
\text { Eğilimi }\end{array}$ & $\begin{array}{l}\text { Beslenme } \\
\text { Alışkanlık } \\
\text { ları }\end{array}$ & $\begin{array}{l}\text { Okul } \\
\text { Terki }\end{array}$ & $\begin{array}{l}\text { Madde } \\
\text { Kullanımı }\end{array}$ \\
\hline $\begin{array}{l}\text { Cinsiyet } \\
\text { Erkek } \\
\text { Kadın } \\
\text { test değeri }\end{array}$ & $\begin{array}{l}2,09 \pm 0,75 \\
1,71 \pm 0,43 \\
\mathbf{t = 2 , 7 7 8} \\
\mathbf{p = , 0 0 9 *} \\
\end{array}$ & $\begin{array}{l}1,30 \pm 0,63 \\
1,14 \pm 0,47 \\
U=2707,5 \\
p=, 122 \\
\end{array}$ & $\begin{array}{l}1,96 \pm 0,99 \\
1,48 \pm 0,69 \\
\mathbf{U = 1 9 9 5 , 5} \\
\mathbf{p}=, \mathbf{0 0 2} * \\
\end{array}$ & $\begin{array}{l}2,09 \pm 0,75 \\
1,71 \pm 0,43 \\
t=-, 828 \\
p=, 408\end{array}$ & $\begin{array}{l}2,87 \pm 0,69 \\
2,82 \pm 0,72 \\
t=, 369 \\
p=, 713 \\
\end{array}$ & $\begin{array}{l}2,35 \pm 0,91 \\
1,90 \pm 0,77 \\
\mathbf{t}=\mathbf{2 , 9 0 9} \\
\mathbf{p}=, \mathbf{0 0 4} *\end{array}$ & $\begin{array}{l}1,21 \pm 0,43 \\
1,07 \pm 0,31 \\
\mathbf{U}=\mathbf{2 2 1 7 , 0} \\
\mathbf{p}=\mathbf{0 0 0} *\end{array}$ \\
\hline $\begin{array}{l}\text { Yaş } \\
17 \text { ve } 18 \\
19 \\
20 \\
21 \\
22 \text { ve üzeri }\end{array}$ & $\begin{array}{l}1,69 \pm 0,46 \\
1,83 \pm 0,47 \\
1,70 \pm 0,47 \\
1,79 \pm 0,66 \\
1,71 \pm 0,48\end{array}$ & $\begin{array}{l}1,18 \pm 0,64 \\
1,08 \pm 0,29 \\
1,15 \pm 0,43 \\
1,29 \pm 0,62 \\
1,44 \pm 0,79\end{array}$ & $\begin{array}{l}1,56 \pm 0,82 \\
1,43 \pm 0,64 \\
1,50 \pm 0,50 \\
1,72 \pm 1,00 \\
2,13 \pm 1,13\end{array}$ & $\begin{array}{l}2,41 \pm 0,76 \\
2,41 \pm 0,72 \\
2,39 \pm 0,60 \\
2,13 \pm 0,54 \\
2,23 \pm 0,75\end{array}$ & $\begin{array}{l}2,94 \pm 0,76 \\
2,80 \pm 0,74 \\
2,91 \pm 0,66 \\
2,59 \pm 0,67 \\
2,68 \pm 0,54\end{array}$ & $\begin{array}{l}1,81 \pm 0,69 \\
1,88 \pm 0,74 \\
2,11 \pm 0,93 \\
2,12 \pm 0,75 \\
2,15 \pm 1,05\end{array}$ & $\begin{array}{l}1,03 \pm 0,08 \\
1,06 \pm 0,35 \\
1,06 \pm 0,15 \\
1,20 \pm 0,53 \\
1,30 \pm 0,58\end{array}$ \\
\hline test değeri & $\begin{array}{l}F=, 896 \\
p=, 467\end{array}$ & $\begin{array}{l}X^{2}=5,013 \\
p=, 286\end{array}$ & $\begin{array}{l}X^{2}=6,389 \\
p=, 172\end{array}$ & $\begin{array}{l}\mathrm{F}=1,183 \\
\mathrm{p}=, 319\end{array}$ & $\begin{array}{l}F=1,509 \\
p=, 201\end{array}$ & $\begin{array}{l}F=1,595 \\
p=, 177\end{array}$ & $\begin{array}{l}X^{2}=10,501 \\
p=, 033 *\end{array}$ \\
\hline $\begin{array}{l}\text { Anne eğitim } \\
\text { durumu } \\
\text { Okur yazar } \\
\text { değil }\end{array}$ & $2,01 \pm 0,66$ & $1,14 \pm 0,45$ & $1,57 \pm 0,84$ & $2,46 \pm 0,65$ & $2,90 \pm 0,65$ & $1,93 \pm 0,89$ & $1,06 \pm 0,16$ \\
\hline $\begin{array}{l}\text { İlköğretim } \\
\text { lise } \\
\text { üniversite ve } \\
\text { üstü } \\
\text { test değeri }\end{array}$ & $\begin{array}{l}1,72 \pm 0,44 \\
1,70 \pm 0,47 \\
1,67 \pm 0,51 \\
\mathbf{F = 3 , 4 8 9} \\
\mathbf{p = , 0 1 7} * \\
\end{array}$ & $\begin{array}{l}1,13 \pm 0,47 \\
1,27 \pm 0,56 \\
1,27 \pm 0,71 \\
\\
X^{2}=7,006 \\
p=, 072\end{array}$ & $\begin{array}{l}1,46 \pm 0,63 \\
1,71 \pm 0,90 \\
2,07 \pm 1,14 \\
X^{2}=6,534 \\
p=, 088 \\
\end{array}$ & $\begin{array}{l}2,38 \pm 0,66 \\
2,24 \pm 0,77 \\
2,35 \pm 0,62 \\
\mathrm{~F}=, 824 \\
\mathrm{p}=, 482\end{array}$ & $\begin{array}{c}2,87 \pm 0,73 \\
2,67 \pm 0,72 \\
2,75 \pm 0,60 \\
\\
F=1,141 \\
\mathrm{p}=, 333 \\
\end{array}$ & $\begin{array}{l}1,98 \pm 0,80 \\
1,95 \pm 0,78 \\
1,82 \pm 0,57 \\
\mathrm{~F}=, 113 \\
\mathrm{p}=, 953\end{array}$ & $\begin{array}{l}1,05 \pm 0,24 \\
1,20 \pm 0,55 \\
1,06 \pm 0,17 \\
X^{2}=7,167 \\
p=, 067\end{array}$ \\
\hline $\begin{array}{l}\text { Baba eğitim } \\
\text { durumu } \\
\text { Okur yazar } \\
\text { deŏil }\end{array}$ & $1,99 \pm 0,65$ & $1,26 \pm 0,58$ & $1,51 \pm 0,79$ & $2,45 \pm 0,50$ & $2,91 \pm 0,73$ & $2,10 \pm 0,97$ & $1,12 \pm 0,41$ \\
\hline $\begin{array}{l}\text { İlköğretim } \\
\text { lise } \\
\text { üniversite ve } \\
\text { üstü } \\
\text { test değeri }\end{array}$ & 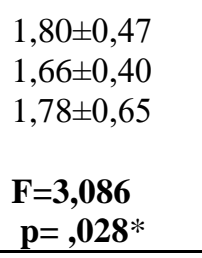 & $\begin{array}{l}1,13 \pm 0,53 \\
1,14 \pm 0,37 \\
1,28 \pm 0,63 \\
\\
X^{2}=3,981 \\
p=, 264 \\
\end{array}$ & $\begin{array}{l}1,50 \pm 0,75 \\
1,52 \pm 0,68 \\
1,85 \pm 0,92 \\
X^{2}=6,102 \\
p=, 107 \\
\end{array}$ & $\begin{array}{l}2,42 \pm 0,64 \\
2,27 \pm 0,77 \\
2,35 \pm 0,66 \\
\mathrm{~F}=, 840 \\
\mathrm{p}=, 473\end{array}$ & $\begin{array}{l}2,89 \pm 0,75 \\
1,88 \pm 0,71 \\
2,88 \pm 0,76 \\
\mathrm{~F}=1,109 \\
\mathrm{p}=, 346\end{array}$ & $\begin{array}{l}2,03 \pm 0,83 \\
1,88 \pm 0,78 \\
1,88 \pm 0,82 \\
\mathrm{~F}=, 853 \\
\mathrm{p}=, 467\end{array}$ & $\begin{array}{l}1,07 \pm 0,35 \\
1,11 \pm 0,34 \\
1,03 \pm 0,10 \\
X^{2}=3,790 \\
p=, 285\end{array}$ \\
\hline $\begin{array}{l}\text { Mevcut ilişki } \\
\text { durumu } \\
\text { evet } \\
\text { hayır }\end{array}$ & $\begin{array}{l}1,71 \pm 0,40 \\
1,79 \pm 0,54\end{array}$ & $\begin{array}{l}1,20 \pm 0,46 \\
1,15 \pm 0,51\end{array}$ & $\begin{array}{l}1,76 \pm 0,79 \\
1,46 \pm 0,72\end{array}$ & $\begin{array}{l}2,27 \pm 0,75 \\
2,40 \pm 0,66\end{array}$ & $\begin{array}{l}2,77 \pm 0,66 \\
2,85 \pm 0,74\end{array}$ & $\begin{array}{l}2,05 \pm 0,83 \\
1,93 \pm 0,79\end{array}$ & $\begin{array}{l}1,12 \pm 0,32 \\
1,07 \pm 0,34\end{array}$ \\
\hline test değeri & $\begin{array}{l}\mathrm{t}=-1,242 \\
\mathrm{p}=, 216\end{array}$ & $\begin{array}{l}U=4959,0 \\
p=, 074\end{array}$ & $\begin{array}{l}\mathrm{U}=3846,0 \\
\mathrm{p}=, \mathbf{0 0 0} *\end{array}$ & $\begin{array}{l}t=-1,293 \\
p=, 197\end{array}$ & $\begin{array}{l}\mathrm{t}=-, 752 \\
\mathrm{p}=, 453\end{array}$ & $\begin{array}{l}\mathrm{t}=1,042 \\
\mathrm{p}=, 298\end{array}$ & $\begin{array}{l}U=4671,000 \\
p=, 004 *\end{array}$ \\
\hline
\end{tabular}

\begin{tabular}{|c|c|c|c|c|c|c|c|}
\hline $\begin{array}{l}\text { Önceki ilişki } \\
\text { durumu } \\
\text { evet }\end{array}$ & $1,77 \pm 0,55$ & $1,25 \pm 0,56$ & $1,80 \pm 0,92$ & $2,34 \pm 0,74$ & $2,90 \pm 0,72$ & $2,01 \pm 0,87$ & $1,13 \pm 0,35$ \\
\hline hayır & $1,75 \pm 0,46$ & $1,10 \pm 0,44$ & $1,37 \pm 0,55$ & $2,37 \pm 0,65$ & $2,76 \pm 0,70$ & $1,93 \pm 0,75$ & $1,06 \pm 0,31$ \\
\hline test değeri & $\begin{array}{l}\mathrm{t}=, 379 \\
\mathrm{p}=, 705\end{array}$ & $\begin{array}{l}\mathrm{U}=5373,0 \\
\mathrm{p}=, 005^{*}\end{array}$ & $\begin{array}{l}\mathrm{U}=4485,5 \\
\mathrm{p}=, 000 *\end{array}$ & $\begin{array}{l}t=-, 346 \\
p=, 730\end{array}$ & $\begin{array}{l}t=1,424 \\
p=, 156\end{array}$ & $\begin{array}{l}t=, 787 \\
p=, 432\end{array}$ & $\begin{array}{l}\mathrm{U}=5710,0 \\
\mathrm{p}=, 068\end{array}$ \\
\hline
\end{tabular}

$* \mathrm{p}<0,05$ 
Üniversite öğrencilerinin WOQOL-BREF puanlarına göre öğrencilerin cinsiyet ve yaş değişkenlerine göre anlamlı farklılık saptanmamıştır $(p>0,05)$. Ek olarak bireyin mevcut ilişki durumu ve önceki ilişki durumu değişkenleri de WOQOL-BREF boyutlarında istatistiksel anlamlılıkta bir farkl111k göstermemiştir $\quad(p>0,05) . \quad$ Üniversite öğrencilerinin WOQOL-BREF çevre alanı, anne eğitim düzeyine göre anlamlı farkl11ık göstermektedir $(\mathrm{p}<0,05)$. Annesi okur yazar olmayan öğrencilerin puan ortalaması diğer gruplara göre daha düşük düzeyde bulunmuştur. Annesi okur yazar olmayan öğrencilerin çevre boyutu daha düşük düzeydedir (Tablo 4).

Üniversite öğrencilerinin WOQOL-BREF sosyal ilişkiler ve çevre boyutları da, baba eğitim düzeyine göre anlamlı farkl1lık göstermektedir $(\mathrm{p}<0,05)$. Babası okur yazar olmayan öğrencilerin sosyal ilişkiler boyutu puan ortalaması ile çevre boyutu puan ortalaması diğer gruplara göre daha düşük düzeyde bulunmuştur. Babası okur yazar olmayan öğrencilerin sosyal ilişkiler ve çevre boyutları daha düşük düzeyde olduğu belirlenmiş̧tir (Tablo 4). Yaşam kalitesinin değerlendirilmesinde, anne eğitim düzeyi düşük olan öğrencilerde çevre alanı puan ortalaması daha düşüktür. Çevre alanı ile ilgili yaşam doyumu; maddi olanaklar, sağlık hizmetlerine erişebilirlik, ev ortamı, dinlenme ve boş zamanları değerlendirme firsatı, fiziksel güvenlik ve ulaşım gibi özellikler açılanabilir. Baba eğitim düzeyinin artması, yaşam kalitesinin alt boyutları olan sosyal ilişkiler ve çevre alanlarını da olumlu yönde etkilemiștir. Anne ve baba eğitim düzeyleri ile 10 yaş çocuğunun duygusal zeka performans1 arasındaki ilişkiyi inceleyen bir çalışmada annenin eğitim düzeyi ile çocuğun duygusal zeka performansının daha yüksek ilişkiye sahip olduğu saptanmıştır. ${ }^{36}$ Annelerin çocuklarıyla küçük yaşlardan itibaren duygusal paylaşımlarda bulunması kişinin ileri dönemlerdeki yaşam kalitesini olumlu etkileyebileceğini düşündürebilir. Ayrıca duygusal zeka becerilerinin etkisi, kişinin akademik başarısında, olumlu sosyal ilişkilerinde, yaşam doyumunda ve iyi oluş düzeyinde etkilidir. ${ }^{37,38,39} \mathrm{Bu}$ bağlamda anne ve babanın eğitim durumunun artması ile çocuklarına daha fazla destek olabileceği düşünülür.

Tablo 4. WOQOL-BREF Boyutlarının Demografik ve Flört Şiddetine İlişkin Özellikler Açısından Incelenmesi

\begin{tabular}{|c|c|c|c|c|c|}
\hline $\begin{array}{l}\text { Demografik ve flört } \\
\text { şiddetine ilişkin özellikler }\end{array}$ & $\begin{array}{l}\text { Genel sağlık } \\
\text { durumu }\end{array}$ & $\begin{array}{l}\text { Fiziksel } \\
\text { sağlık }\end{array}$ & $\begin{array}{l}\text { Psikolojik } \\
\text { durum }\end{array}$ & $\begin{array}{l}\text { Sosyal } \\
\text { İlişkiler }\end{array}$ & Çevre \\
\hline $\begin{array}{l}\text { Cinsiyet } \\
\text { Erkek } \\
\text { Kadın } \\
\text { test değeri }\end{array}$ & $\begin{array}{l}3,03 \pm 0,67 \\
3,20 \pm 0,52 \\
t=-1,578 \\
p=, 116\end{array}$ & $\begin{array}{l}3,64 \pm 0,45 \\
3,57 \pm 0,54 \\
t=, 654 \\
p=, 514\end{array}$ & $\begin{array}{l}3,24 \pm 0,41 \\
3,22 \pm 0,55 \\
t=, 214 \\
p=, 831\end{array}$ & $\begin{array}{l}3,06 \pm 0,61 \\
3,17 \pm 0,54 \\
t=-, 970 \\
p=, 333\end{array}$ & $\begin{array}{l}3,19 \pm 0,35 \\
3,13 \pm 0,44 \\
\mathrm{t}=, 737 \\
\mathrm{p}=, 462\end{array}$ \\
\hline $\begin{array}{l}\text { Yaş } \\
17 \text { ve } 18 \\
19 \\
20 \\
21 \\
22 \text { ve üzeri } \\
\text { test değeri }\end{array}$ & $\begin{array}{l}3,14 \pm 0,51 \\
3,19 \pm 0,55 \\
3,21 \pm 0,58 \\
3,18 \pm 0,60 \\
3,04 \pm 0,40 \\
\mathrm{~F}=, 302 \\
\mathrm{p}=, 876\end{array}$ & $\begin{array}{l}3,56 \pm 0,57 \\
3,58 \pm 0,58 \\
3,64 \pm 0,47 \\
3,50 \pm 0,40 \\
3,57 \pm 0,49 \\
\mathrm{~F}=, 381 \\
\mathrm{p}=, 822 \\
\end{array}$ & $\begin{array}{l}3,23 \pm 0,59 \\
3,18 \pm 0,57 \\
3,24 \pm 0,53 \\
3,32 \pm 0,37 \\
3,17 \pm 0,37 \\
\mathrm{~F}=, 446 \\
\mathrm{p}=, 775\end{array}$ & $\begin{array}{l}3,23 \pm 0,62 \\
3,15 \pm 0,57 \\
3,14 \pm 0,45 \\
3,11 \pm 0,49 \\
3,00 \pm 0,68 \\
\mathrm{~F}=, 540 \\
\mathrm{p}=, 706\end{array}$ & $\begin{array}{l}3,15 \pm 0,50 \\
3,13 \pm 0,43 \\
3,15 \pm 0,43 \\
3,10 \pm 0,37 \\
3,17 \pm 0,34 \\
\mathrm{~F}=, 105 \\
\mathrm{p}=, 981\end{array}$ \\
\hline $\begin{array}{l}\text { Anne eğitim düzeyi } \\
\text { okuma- yazma yok } \\
\text { İlköğretim } \\
\text { lise } \\
\text { üniversite ve üstü } \\
\text { test değeri }\end{array}$ & $\begin{array}{l}3,16 \pm 0,64 \\
3,17 \pm 0,54 \\
3,24 \pm 0,52 \\
3,00 \pm 0,41 \\
F=, 460 \\
p=, 711\end{array}$ & $\begin{array}{l}3,60 \pm 0,53 \\
3,58 \pm 0,50 \\
3,58 \pm 0,57 \\
3,61 \pm 0,58 \\
F=, 018 \\
p=, 997\end{array}$ & $\begin{array}{l}3,15 \pm 0,57 \\
3,22 \pm 0,51 \\
3,28 \pm 0,56 \\
3,26 \pm 0,49 \\
F=, 419 \\
p=, 739\end{array}$ & $\begin{array}{l}3,09 \pm 0,53 \\
3,11 \pm 0,52 \\
3,30 \pm 0,61 \\
3,33 \pm 0,67 \\
F=1,951 \\
p=, 122\end{array}$ & $\begin{array}{l}2,99 \pm 0,40 \\
3,13 \pm 0,44 \\
3,26 \pm 0,40 \\
3,13 \pm 0,29 \\
\mathbf{F}=\mathbf{2 , 8 7 5} \\
\mathbf{p}=, \mathbf{0 3 7} *\end{array}$ \\
\hline
\end{tabular}


Tablo 4 (Devamı). WOQOL-BREF Boyutlarının Demografik ve Flört Şiddetine İlişkin Özellikler Açısından İncelenmesi

\begin{tabular}{|c|c|c|c|c|c|}
\hline $\begin{array}{l}\text { Baba eğitim düzeyi } \\
\text { okuma- yazma yok } \\
\text { İlköğretim } \\
\text { lise } \\
\text { üniversite ve üstü }\end{array}$ & $\begin{array}{l}3,09 \pm 0,58 \\
3,20 \pm 0,59 \\
3,21 \pm 0,51 \\
3,04 \pm 0,48\end{array}$ & $\begin{array}{l}3,48 \pm 0,40 \\
3,57 \pm 0,51 \\
3,60 \pm 0,59 \\
3,63 \pm 0,46\end{array}$ & $\begin{array}{l}3,15 \pm 0,47 \\
3,19 \pm 0,55 \\
3,23 \pm 0,55 \\
3,37 \pm 0,43\end{array}$ & $\begin{array}{l}2,91 \pm 0,59 \\
3,07 \pm 0,59 \\
3,27 \pm 0,50 \\
3,30 \pm 0,43\end{array}$ & $\begin{array}{l}2,96 \pm 0,37 \\
3,09 \pm 0,44 \\
3,21 \pm 0,45 \\
3,22 \pm 0,35\end{array}$ \\
\hline test değeri & $\begin{array}{l}F=, 994 \\
p=, 396\end{array}$ & $\begin{array}{l}F=, 388 \\
p=, 762\end{array}$ & $\begin{array}{l}F=, 975 \\
p=, 405\end{array}$ & $\begin{array}{l}F=4,198 \\
p=, 006^{*}\end{array}$ & $\begin{array}{c}\mathrm{F}=\mathbf{2 , 9 2 1} \\
\mathbf{p}=, 035^{*}\end{array}$ \\
\hline $\begin{array}{l}\text { Mevcut ilişki durumu } \\
\text { evet } \\
\text { hayır }\end{array}$ & $\begin{array}{l}3,24 \pm 0,52 \\
3,15 \pm 0,56\end{array}$ & $\begin{array}{l}3,63 \pm 0,57 \\
3,56 \pm 0,51\end{array}$ & $\begin{array}{l}3,26 \pm 0,48 \\
3,21 \pm 0,55\end{array}$ & $\begin{array}{l}3,26 \pm 0,59 \\
3,11 \pm 0,53\end{array}$ & $\begin{array}{l}3,17 \pm 0,47 \\
3,13 \pm 0,41\end{array}$ \\
\hline test değeri & $\begin{array}{l}\mathrm{t}=1,096 \\
\mathrm{p}=, 456\end{array}$ & $\begin{array}{l}\mathrm{t}=-, 947 \\
\mathrm{p}=, 344\end{array}$ & $\begin{array}{c}\mathrm{t}=-, 340 \\
\mathrm{p}=, 734\end{array}$ & $\begin{array}{c}\mathrm{t}=-1,564 \\
\mathrm{p}=, 119\end{array}$ & $\begin{array}{l}\mathrm{t}=-, 543 \\
\mathrm{p}=, 587\end{array}$ \\
\hline $\begin{array}{l}\text { Önceki ilişki durumu } \\
\text { evet } \\
\text { hayır }\end{array}$ & $\begin{array}{l}3,14 \pm 0,56 \\
3,20 \pm 0,54\end{array}$ & $\begin{array}{l}3,54 \pm 0,52 \\
3,61 \pm 0,54\end{array}$ & $\begin{array}{l}3,21 \pm 0,55 \\
3,23 \pm 0,52\end{array}$ & $\begin{array}{c}3,08 \pm 0,60 \\
3,20 \pm 0,51\end{array}$ & $\begin{array}{l}3,12 \pm 0,41 \\
3,15 \pm 0,44\end{array}$ \\
\hline test değeri & $\begin{array}{l}\mathrm{t}=-, 746 \\
\mathrm{p}=, 456\end{array}$ & $\begin{array}{l}\mathrm{t}=-, 947 \\
\mathrm{p}=, 344\end{array}$ & $\begin{array}{l}\mathrm{t}=-, 340 \\
\mathrm{p}=, 734\end{array}$ & $\begin{array}{l}t=-1,564 \\
p=, 119\end{array}$ & $\begin{array}{l}t=-, 543 \\
p=, 587\end{array}$ \\
\hline
\end{tabular}

*p<0,05

Katılımcıların FŞYTÖ alt boyutlarından Erkeğin Flörtte Uyguladığı Fiziksel Flört Şiddetine Yönelik Tutumlar Ölçeği puanı ile çevre boyutu arasında negatif yönlü zayıf bir ilişki bulunmaktadır $(\mathrm{r}=-, 147 \mathrm{p}<0,05)$ (Tablo 4). Bir diğer boyut olan Kadının Flörtte Uyguladığı Psikolojik Şiddete Karşın Tutum Ölçeği ile genel sağlık durumu arasında negatif yönlü zayıf bir ilişki bulunmaktadır $(\mathrm{r}=-, 147 \quad \mathrm{p}<0,05) \quad$ (Tablo 5). Ek olarak Kadının Flörtte Uyguladığı Fiziksel Şiddete Yönelik Tutum Ölçeği ile Sosyal İlişkiler boyutu arasında negatif yönlü zayıf ilişki ( $\mathrm{r}=$ ,195 p<0,05) çevre boyutu arasında da negatif yönlü zayıf bir ilişki olduğu belirlenmiştir ( $\mathrm{r}=-$-,133 $\mathrm{p}<0,05)$ (Tablo 5).

Tablo 5. FŞYTÖ ile WOQOL-BREF Arasındaki İlişkinin İncelenmesi

\begin{tabular}{|c|c|c|c|c|c|}
\hline \multirow[b]{2}{*}{ FŞYTÖ alt boyutları } & \multicolumn{5}{|c|}{ WOQOL-BREF alt boyutları } \\
\hline & $\begin{array}{l}\text { Genel Sağlık } \\
\text { Durumu }\end{array}$ & $\begin{array}{l}\text { Fiziksel } \\
\text { Sağlık }\end{array}$ & Psikolojik & $\begin{array}{c}\text { Sosyal } \\
\text { İlişkiler }\end{array}$ & Çevre \\
\hline $\begin{array}{l}\text { Erkeğin Flörtte Uyguladığı Psikolojik } \\
\text { Şiddete Yönelik Tutum Ölçeği }\end{array}$ &,- 061 &,- 010 &,- 041 &,- 116 &,- 023 \\
\hline 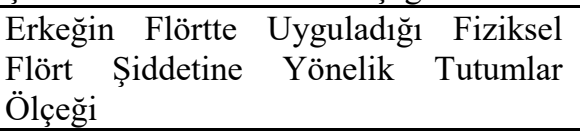 &,- 027 &,- 019 &,- 047 &,- 090 &,$- 147^{*}$ \\
\hline $\begin{array}{l}\text { Kadının Flörtte Uyguladığı Psikolojik } \\
\text { Şiddete Yönelik Tutum Ölçeği }\end{array}$ &,$- 147^{*}$ &,- 045 &,- 099 &,$- 154^{*}$ &,- 099 \\
\hline $\begin{array}{l}\text { Kadının Flörtte Uyguladığı Fiziksel } \\
\text { Şiddete Yönelik Tutum Ölçeği }\end{array}$ &,- 103 &,- 032 &,- 059 &,$- 195^{* *}$ &,$- 133^{*}$ \\
\hline
\end{tabular}

Ayrıca araştırma bulgularına göre Kadının Flörtte Uyguladiğ 1 Psikolojik Şiddete Yönelik Tutum Ölçeği, genel sağllk durumunu negatif yönde etkilemektedir $(B=-$ ,131 $\mathrm{p}<0,05)$. Genel sağlık durumu alanındaki değişimin \%2'si kadının flörtte uyguladığı psikolojik şiddete özgü tutum ölçeği tarafından açıklanmaktadır.
Kadının flörtte gösterdiği psikolojik şiddete yönelik tutum ölçeği, sosyal ilişkileri negatif yönde etkilemektedir $(B=-, 156$ $\mathrm{p}<0,05)$. Sosyal ilişkiler alanındaki değişimin \%4'ü Kadının Flörtte Uyguladığı Psikolojik Şiddete Yönelik Tutum Ölçeği tarafından açıklanmaktadır (Tablo 6). Erkeğin Flörtte Uyguladığı Fiziksel Flört Şiddetine Yönelik 


\section{SONUÇ VE ÖNERILLER}

Flört şiddeti kabul düzeyi bireyin genel sağlık durumu, sosyal ilişkileri ve çevre alanı boyutlarını etkilemektedir. Adölesanlara flört şiddeti hakkında kapsamlı bilgilerin verilmesi, bu durum ile karşılaştıklarında nasıl baş edebilecekleri yönünde farkındalık kazandırılması gerekmektedir. İlaveten yaşanan ciddi flört şiddeti, yaşam kalitesinde azalma, olumsuz sağlık davranıșları ile ilişkilidir. Flört şiddetinin etkisini azaltmak, erken teşhis ve müdahale etmek için flört şiddeti taraması önerilir. Bu çalışmadan elde edilen veriler doğrultusunda üniversite öğrencileri arasında flört şiddet kabul düzeyi, bireyin sosyal ilişkilerini, çevresini ve genel sağlık durumunu etkilemekte, mevcut ilişkisi bulanan öğrencilerde sigara ve madde kullanım riskli davranış düzeylerinin daha fazla olduğu saptanmıştır. $\mathrm{Bu}$ sonuçtan dolayı üniversite öğrencilerinde görülebilen flört şiddeti etkileri ve ilişkili olduğu faktörler hakkında farkındalık yaratılmalıdır. Flört şiddetinin birey üzerinde nedenleri ve sonuçlarını değerlendirmek için daha detaylı çalıșmalara ihtiyaç vardır.

\section{KAYNAKLAR}

1. World Health Organization. (2012). World Report on Violence and Health. Geneva: WHO.http://www5.who.int/violence_injury_prevention/do wnload.cfm?id=0000000582.

2. Kemerli, N. (2003). Aile içi kadına yönelik şiddet, Kadına Yönelik Şiddet ve Hekimlik Sempozyumu Kitab1, 41-59, Ankara, Ankara Tabip Odası Yayınları.

3. İftar, M. (2016). Üniversite Öğrencilerinin Flört Şiddetine Yönelik Tutum ve Davranışları. Muğla Sitkı Koçman Üniversitesi, (Yüksek lisans Tezi) Sağlık Bilimleri Enstitüsü, Muğla.

4. Bal, N. (2014). "Sosyolojide Siddet Kavramı', 6-22. https://yurtvedunyadergisi.files.wordpress.com/2014/02/63.pdf

5. National Youth Violence Prevention Resource Center (2001). Intimate Partner and Family Violence.

6. Furlong, M, Felix, E, Simental, J, Greaf, J, Klein, A Gonzales, M. and Austin, G. ''Dating Violence Patterns of California Adolescents'. (2004). Persistently Safe Schools: The National Conference of The Hamilton Fish Institute on School and Community Violence'da sunulan bildiri.

7. Amerikan Psikiyatri Birliği (2014). Ruhsal Bozuklukların Tanısal ve Sayımsal Elkitabı. Ankara: Hekimler Yayın Birliği.

8. Kılınçer, A.S. ve Tuzgöl, Dost, M. (2014). "Üniversite Öğrencilerinin Romantik İlişkilerinde Algıladıkları İstismar". Türk Psikolojik Danışma ve Rehberlik Dergisi, 5 (42)

9. Subaşı, N. ve Akın, A. (2003). 'Kadına Yönelik Şiddet Nedenleri ve Sonuçları',. Toplumsal Cinsiyet Sağlık ve Kadın, Hacettepe Üniversitesi Kadın Sorunları Araștırma ve Uygulama Merkezi, Hacettepe Üniversitesi Yayınları, 231-248, Ankara.
10. Garcia-Moreno, C, Jansen, A.F.M, Ellsberg, M, Heise, L. and Watts, C.H. (2006). 'WHO Multi-country Study on Women's Health and Domestic Violence against Women Study Team" "Prevalence of Intimate Partner Violence: Findings from the WHO Multi-country Study on Women's Health and Domestic Violence". Lancet, 368, 1260-1269.

11. Basile, K.C, Black, M.C, Breiding, M.J, Chen, J, Merrick, M.T, Smith, S.G. and Walters, M.L. (2011). 'National Intimate Partner And Sexual Violence" Survey; 2010 summary report. Erişim adresi: https://stacks.cdc.gov/view/cdc/11637

12. Casey, E.A. and Nurius, P.S. (2006). "Trends in The Prevalence And Characteristics of Sexual Violence: A Cohort Analysis". Violence and Victims, 21 (5), 629.

13. Zweig, J.M, Lachman, P, Yahner, J. and Dank, M. (2014). "Correlates of Cybdating Abuse Among Teens". Journal of Youth and Adolescence, 43 (8), 1306- 1321.

14. Straus, M.A. (2008). "Dominance And Symmetry İn Partner Violence By Male And Female University Students İn 32 Nations". Children and Youth Services Review, 30, $252-275$.

15. Silverman, J.G, Raj, A, Mucci, L.A. and Hathaway, J.E. (2001). Dating Violence Against Adolescent Girls and Associated Substance Use, Unhealthy Weight Control, Sexual Risk Behavior, Pregnancy and Suicidality". JAMA, $5,572-579$

16. Magdol, L, Moffitt, T.E, Caspi, A, Newman, D.L, Fagan D. and Silva, P.A. (1997). "Gender Differences İn Partner Violence İn A Birth Cohort of 21-Year-Olds: Bridging The Gap Between Clinical And Epidemiological Approaches". J Consult Clin Psych, 65, 68-78.

17. Holt, M.K. and Espelage, D.L. (2005). "Social Support as a Moderator Between Dating Violence Victimization and Depression/Anxiety Among African American and Caucasian Adolescents". School Psychology Review, 3 (3), 309-328. 
18. Zehe, J.M, Colder, C.R, Read, J.P, Wieczorek, W.F Lengua, L.J. (2013). "Social And Generalized Anxiety Symptoms and Alcohol and Cigarette Use in Early Adolescence: The Moderating Role of Perceived Peer Norms". Addictive Behaviors, 38 (4), 1931-193.

19. Bureau of Justice Special Report: Intimate Partner Violence. (2000). Woman Ages 16 To 24 Experience The Highest Per Capita Rates of Intimate Violence-Nearly 20 Per 1000 Women.

20. Price E.L. and Byers, E.S. (1999). "Dating Violence Research Team. The Attitudes Towards Dating Violence Scales: Development and Initial Validation". Journal of Family Violence, 14:351-75.

21. Yumuşak, A. (2013). Üniversite Öğrencilerinin Flört Şiddetine Yönelik Tutumları, Toplumsal Cinsiyetçilik Ve Narsisistik Kișilik Özellikleri Arasındaki İlişki. Gaziosmanpaşa Üniversitesi Eğitim Bilimleri Enstitüsü Eğitim Bilimleri Ana Bilim Dalı Rehberlik ve Psikolojik Danışma Bilim Dalı Yüksek Lisans Tezi, Tokat.

22. Gençtanırım, D. and Ergene, T. (2014). "Riskli Davranışlar Ölçeğinin Geliştirilmesi: Geçerlik ve Güvenirlik Calısmaları". The Journal of Academic Social Science Studies, 25 (1), 125-138.

23. Fidaner, H, Elbi, H. ve Fidaner, C. (1999). "Türkler İçin Sağlık ve Sosyal Bilim Araştırmalarında Kullanılan Liker Tipi Yanıt Ölçekleri: WHOQOL Türkçe Versiyonu Yanıt Skalaları Sonuçları”. Psikiyatri Ruhsal Psikofarmakoloji Dergisi, 7, 41-47.

24. Kaya Sakarya, A. (2013). Üniversitede Öğrenim Gören Genclerde Flörtte Siddet. Necmettin Erbakan Üniversitesi, Eğitim Bilimleri Enstitüsü, Yüksek Lisans Tezi, Konya

25. Sezer, Ö. (2008). “Çiftler Arası Şiddeti Kabul Ölçeği'nin Türkçe'ye Uyarlanması: Geçerlik ve Güvenirlik Çalıșmaları”. İnönü Üniversitesi Eğitim Fakültesi Dergisi, 9 (16)

26. Yıldırım, S. (2016). Üniversite Öğrencilerinin Benlik Saygısı ve Toplumsal Cinsiyet Tutumlarının Flört Siddetine Yönelik Tutumlarına Etkisi. Yüksek Lisans Tezi, Hacettepe Üniversitesi, Ankara.

27. Altuntas, O. ve Altınova, H. (2015). “Toplumsal Cinsiyet Algısı ile Sosyo-Ekonomik Değişkenler Arasındaki İlişkinin Belirlenmesi”. International Periodical For The Languages, Literature And History of Turkish Or Turkic, $10(6), 83-100$

28. Manago, A.M. (2015). "Values for Gender Roles and Relations among High School and Non High School Adolescents in a Maya Community in Chiapas, Mexico". International Jo-urnal of Psychology, 50 (1), 20-28

29. Akın, E. ve Berkem, M. (2012). “İntihar Girişiminde Bulunan Ergenlerde Psikiyatrik Tanıların, Demografik ve Klinik Özelliklerin Değerlendirilmesi”. Firat Tıp Dergisi, 17 (4), 228-232.

30. Telef, B.B. (2014). "Ergenlerde Olumlu ve Olumsuz Duygular İle Riskli Davranıșlar Arasındaki İlișkilerin İncelenmesi”. Kastamonu Eğitim Dergisi, 22 (2), 573- 590.

31. Siyez, M.D. ve Palabıyık, A. (2009). "Günebakan Madde Bağımlılığını Önleme Eğitim Programının Lise Öğrencilerinin Madde Kullanım Sıklığı, Uyusturucu Maddeler Hakkındaki Bilgi Düzeyleri ve Yanlış İnanışları İle Madde Reddetme Becerileri Üzerindeki Etkisi”. Elektronik Sosyal Bilimler Dergisi, 8 (28), 56- 67.

32. Korkut, F. (2004). Okul Temelli Önleyici Rehberlik ve Psikolojik Danışma. Ankara: Anı Yayıncılık.
33. Centers for Disease Control and Prevention. (2006). Physical Dating Violence Among High School StudentsUnited States, 2003. MMWR: Morbidity and Mortality Weekly Report, 55 (19), 532-535.

34. Piko, B. (2000). "Perceived Social Support From Parents And Pers: Which İs The Stronger Predictor Of Adolescent Substance Use?". Substance Use \& Misuse, 35 (4), $617-$ 630

35. Ustabaş, S. (2011). İlköğretim 8.Sınıf Öğrencilerinin Saldırganlık ve Algılanan Sosyal Destek Düzeylerinin Bazı Değişkenlere Göre İncelenmesi. Gazi Üniversitesi Eğitim Bilimleri Enstitüsü Eğitim Bilimleri Anabilim Dalı Yüksek Lisans Tezi, Ankara.

36. Coskun, K. (2017). "Anne ve Baba Eğitim Düzeyleri İle 10 Yaş Çocuğunun Duygusal Zeka Performansı Arasındaki İlişkinin İncelenmesi”. Bayburt Eğitim Fakültesi Dergisi, 12 (23), 185-198.

37. Di Fabio, A. and Kenny, M.E. (2011). "Emotional Intelligence and Perceived Social Support Among Italian High School Students". Journal of Career Development, 1 (1), 1-15

38. Ferrando, M, Prieto, M.D, Almeida, L.S, Ferrandiz, C, Bermejo, R, Lopez-Pina, J.A, Hernandez, D, Sainz, M. and Fernandez, C. (2010). "Trait Emotional İntelligence And Academic Performance: Controlling For The Effects of IQ, Personality, and Self-concept". Journal of Psychoeducational Assessment, 20 (10), 1-10.

39. Qualter, P, Whiteley, Y, Hutchinson, J.M. and Pope, D.J. (2007). "Supporting The Development of Emotional Intelligence Competencies to Ease the Transition From Primary to High School". Educational Psychology in Practice, 23 (1), 79-95. 